\title{
Introduction: Artistic Work as a "Laboratory" of Labour Market Deregulation? ${ }^{1}$
}

\author{
Einführung: Künstlerische Arbeit als «Laboratorium» der Deregulierung \\ des Arbeitsmarktes? \\ Introduction : Le travail artistique : «laboratoire» de la dérégulation \\ des marchés du travail?
}

André Ducret* ${ }^{*}$ Andrea Glauser** ${ }^{*}$ Olivier Moeschler***, and Valérie Rolle****

Nowadays, the arts can often command attention as a "laboratory" for the current forms of labour market deregulation. It is not that artists have been ahead of the transformations that have affected the labour market since the 1980s, but rather that they have, for the most part, escaped the standard of the modern wage system specific to industrial capitalism, now weakened by the hegemony of financial capitalism. Their condition was characterised early on by differing degrees of precariousness, echoed in the last decades by the rise of a precariat, which has been eating away at the omnipresence of wage labour in many sectors of activity (Castel 2009; Lorey 2012; Marchart 2013). Committing oneself without hesitation; displaying autonomy; appearing flexible, mobile, available; knowing how to adapt and move from one project to the next without batting an eyelid; not being afraid to take risks, even when the symbolic benefits seem to prevail over wages; accepting to "multiply oneself" (Menger 1997) or to lead a "double life" (Lahire 2006), in which the day job is bankrolling the calling, thus validating the separation between alienating and rewarding labour (Arendt 1959); finally, making do with earnings that are often unpredictable, inconsistent and unequal according to one's reputation: these are the many features that have long since characterised the "artist's life" and which have

\footnotetext{
* University of Geneva, Institut de recherches sociologiques (IRS), CH-1211 Genève, andre.ducret@ unige.ch.

** University of Lucerne, Department of Sociology, CH-6002 Luzern, andrea.glauser@unilu.ch.

*** University of Lausanne, Laboratoire Culture Capitalisme et Sociétés (LACCUS), CH-1015 Lausanne, olivier.moeschler@unil.ch.

**** Fellow of the Swiss National Science Foundation, London School of Economics and Political Sciences, Department of Sociology, UK-WC2A 2AE London, v.rolle@lse.ac.uk.

1 We wish to warmly thank Sarah-Jane Moloney for the translation of this introduction from French to English, and the Institute for Sociological Research (IRS) of the University of Geneva for sponsoring it.
} 
established themselves, either fully or in part, as an entrepreneurial ideal to be followed in other sectors of employment (Boltanski and Chiapello 1999; Linhart 2015).

\section{The arts: unequal and segmented labour markets}

By the same token, under such working conditions, inequalities between individuals do not seem likely to decrease, particularly in the different creative fields discussed in this issue. In this regard, fragmentation and uncertainty of employment in the artistic labour market are subjected to new forms of collective and individual management, varying according to the historical evolution specific to each artistic genre, its internal hierarchy and the positions occupied by the various players involved. For example, before the interwar years, the regulation of the performing arts market in France (especially theatre, music, cinema) mostly depended on the balance of power between employers and unions. It rested on corporatist solidarities rather than state laws that guaranteed social protection, a system that was set to become widespread during the post-war years, in France and elsewhere. Although a special protection system was already in place for contingent art workers, it was only in 1979 that it would become that well-known French "intermittent regime", whose expansion during the following decades would provoke recurrent conflicts (Grégoire 2013). Nothing of the sort exists in Germany, however, where the logic of the fixed ensemble is still the rule in public theatres; even though the reunification imposed the West's divisions on the East, and pitted public structures where employment is stable, against private structures where employment is flexible and negotiable, work and employment being meted out on a project basis (De Verdalle 2006).

The professional arena will thus always end up divided along the lines of those who have the freedom to take risks - 30-something men, as a general rule - and those who would benefit from settling down - more often than not, women and older individuals. The same applies to German-speaking Switzerland, where the Stadttheater (literally: the "town theatre") offer contracts for the entire season or even several years, according to a "house ensemble" approach, contrary to the majority of other theatres, whether they be subsidised or not. However, in French- and Italianspeaking Switzerland, common practice turns out to be short-term, project-based work, including in large theatre institutions (Kotte et al. 2012). Unlike France, but in the manner of Germany, Switzerland does not have a special system of insurance coverage - even though the access to unemployment benefits has been adapted for artists, on the basis of the prevailing model for seasonal employment. In Frenchspeaking Switzerland, unemployment benefit also plays a stabilising role for actors, particularly when the greater part of their activity answers to a kind of versatility internal to artistic work, rather than a multi-activity implying an accumulation with a job external to the field of performing arts (Rolle and Moeschler 2014). 
Such differences between stable (for a minority of art workers) and unstable employment (for a majority) are also observable between permanent orchestra musicians and musical performers, or even ballet dancers and contemporary dancers, but also writers who benefit from year-long contracts with their publishers, and writers who do not have that privilege. In a fixed organisational structure, the modalities of evolution within a career meet those we can observe on "standard" labour markets - which still prevail - with internal (in the hierarchy of roles or functions) or external forms of promotion or demotion (evolution towards more or less prestigious institutions). When the employment market proves to be flexible, professional trajectories are more splintered, to the point where they can sometimes seem like "improvised careers" (Fabiani 1986). Careers are, in fact, exposed to a greater risk of reversibility (Haak 2008). However, these fluctuations do not exclude the existence of social inequalities. They are nevertheless more and more difficult to discern, playing out as they do at the intersection of the acquisition and the actualisation of resources, as well as variable inclinations according to one's social attributes (belonging to a certain class, gender, age or ethnicity) and professional trajectory (generation, education and training, accumulated experience, positions occupied, type of recognition received, but also sectors of activity). ${ }^{2}$

The extraordinary growth of the number of hopefuls swelling the ranks of the different artistic fields since the 1980s, with knock-on effects such as overcrowding and the constant search for "new blood" (Menger 1991), reinforces such inequalities by accentuating the competition in these markets. The rapid development of the latter owes as much to the expansion of the arts as the symbolic prestige of such activities and the promises of fulfilment they carry, even though the high material profits that can be taken from them are highly improbable, seeing as they are realised only by a handful of generally well-appointed individuals (Abbing 2006; Dubois 2013). This strong power of appeal exerted by the artistic professions more widely echoes the diffusion of an ideal of self-realisation associated with values of freedom, self-determination, authenticity and responsibility - values which are most often carried and promoted by the middle and upper classes. This normative model colours a managerial rhetoric whose tendency is to over-humanise work by demanding a total compliance to the objectives pursued by the firm or the work team (Klein and Kunst 2012; Linhart 2015; Manske 2015).

2 The disparities between individuals are even greater in sectors where freelance status is the rule, such as the visual arts or literature, compared to fields where fixed employment exists (theatre or dance troupes, orchestras), albeit where a majority do not manage to obtain employee status. 


\section{The arts: no longer exceptional with the growth of non-standard work}

This "new spirit of capitalism" (Boltanski and Chiapello 1999), which seizes upon and harnesses the vocational logic of the arts, values forms of project- and network-organised labour, holding up the myth of freedom and authenticity as a model. These forms lead to an individualisation of employment relationships, as well as varied types of "crumbling" (Castel 2009) of this relationship through a flexibilisation of tasks (versatility), working hours (part-time, fixed-term contracts, home-based work), and/or the workforce (on-call work, temping, outsourcing). According to the forms and amount of their capital and their position in the labour market, individuals do not have the same bargaining power when faced with these forms of work organisation ${ }^{3}$, nor do they have the same frames of resistance to deal with the suffering they can entail. Even less so, given the more general context of depoliticisation and re-assessment of the welfare state and its associated rights, with forms of access to compensation conditioned by activation measures in the workplace, which blur the lines between wage labour, unemployment and benefits (Kuehni 2016; Schallberger and Wyer 2010).

By focusing on one dimension or another of the structuration of labour markets in the arts or the concrete organisation of artistic activities, the contributions we will read offer entirely original and complementary analyses, in order to understand the sector specificities of a labour market that might be considered "atypical", but whose many particularities no longer constitute exceptions in this day and age. They remind us that the ideal of the self-regulation of the arts, which justifies forms of deregulation elsewhere, is more of a myth than a reality. Indeed, the case of the arts shows to what extent the "freedom" we ascribe to artists is in fact beholden to an undeniable heteronomy, with respect to the markets as well as the public authorities upon which it depends. The "responsibility" that goes hand in hand with this freedom - which is supposed to accompany the individualisation of work relationships - also exposes individuals to very unequal risks, according to the personal resources they possess.

Regulation, deregulation, self-regulation: economists are all equally fond of these concepts, but their translation into the field of sociology is hardly self-evident. The adoption and use of these terms by sociologists of the arts and culture might perhaps point to their difficulty in proving how fertile and useful this field of research can be for understanding Swiss society - let alone how crucial (Ducret 2011). In France - another geographical area explored in this issue - the directions taken by our particular sub-field of study owe a lot to the presence of instances such as the French Ministry of Cultural Affairs, created in 1959. The Ministry gave the impetus for one of the first-ever surveys carried out on the museum-going public (Bourdieu and Darbel 1966), and later on, many statistical surveys about artistic professions.

3 Young people, women and the under-qualified are most at risk according to the literature. 
In this respect, we have only to think of the work carried out by the Centre for Research in Sociology of the Arts (Centre de recherche en sociologie des arts), led by Raymonde Moulin and followed by Pierre-Michel Menger. In Germany - the third main area discussed in this issue - there has been a rich tradition of reflection on the arts within universities, from Georg Simmel to Norbert Elias, or from Theodor W. Adorno to Niklas Luhmann, to name but a few (Steuerwald 2016). Admittedly, this legacy is more theoretical than empirical, with extensive fieldwork now taking over, including in Germany. ${ }^{4}$ The task that remains, however, is to reconstruct the history of the structuration of sociology of the arts and culture in Switzerland; scientific, political and even geographical logics intertwine to explain Switzerland's relative delay regarding its research into the matter.

\section{Research on the arts and culture running late in the Swiss context}

It must be said that Switzerland waited until the year 2000 to adopt a proper constitutional article concerning culture. Formulated on this basis, the first federal law on culture (the LEC, Loi sur l'encouragement de la culture, or Cultural Promotion $A c t^{5}$ ), which entered into effect in 2012, has since been contributing to transforming the Swiss cultural landscape, in accordance with the principle of subsidiarity which had prevailed until then, and which delegates the principal responsibility for financing this sector to individual cantons and communes (Marx 2015). At a federal level, culture mostly constitutes a tool for the international promotion of the Confederation via the Pro Helvetia foundation. The latter is an atypical organisation in federalist territories. Dedicated to the promotion of culture, it was founded within the very specific context of the rise of totalitarian regimes that led to the Second World War (Hauser et al. 2010). As for cinema - which has been subsidised on a national scale since the emergence of "New Swiss Cinema" and the consecration of the film director's status in the 60s and 70s - it has long represented a kind of "cultural exception" (Moeschler 2011), confirming the rule that Switzerland is a rather discreet state when it comes to cultural policy (Walzer 1988). However, since the ratification of the LEC, new elements have been added to the mix, such as the promotion of musical training and cultural heritage, as well as national awards for creatives (visual arts, design, cinema, dance, theatre, music and literature). At the same time, interest in culture as a vector for social integration and economic innovation has grown to such an extent that, beyond the question of the cost of culture for

$4 \quad$ For a first list of achievements, and in a necessarily limited format, the reader can refer to the syntheses proposed by Nathalie Heinich (2004 [2001]), Bruno Péquignot (2009) and more recently, Hyacinthe Ravet (2015) (for France). Dagmar Danko (2012) and Alfred Smudits (2013) offer an overview of the sociology of art from a German-speaking perspective, whereas Dagmar Danko and Andrea Glauser (2012) principally take stock of the situation in Germany. Available on the internet: http://www.bak.admin.ch/themen/04128/index.html?lang=fr. 
local authorities - the only such aspect to have been subjected to follow-up statistical reports until now ${ }^{6}$ - the Federal Office of Culture (OFC-BAK) now wants to see more numbers published and has been addressing such requests to the Federal Statistical Office (OFS-BFS). Consequently, the new sectors included in the forms of culture backed by the Confederation (such as museums, monuments, heritage or even "the culture economy") are now subject to statistical quantification. The question has also been asked as to how we might, in the future, be able to produce numbers regarding arts professionals; these are, at the moment, too erratic to be exploited. ${ }^{7}$ Finally, from the point of view of cultural practices, the Federal Statistical Office has begun to produce more data since 2008, after having undertaken a reworking of its categories; this effort consisted of redefining the aforementioned cultural practices as "demand" in the face of a cultural "supply" now put on notice to justify its costs (Moeschler and Vanhooydonck 2011). Nevertheless, it must be noted that such statistics can hold an interest for the sociology of the arts and culture, and feed its research (see for example Tawfik 2013).

For Switzerland, a federalist country built on the crossroads of linguistic areas, culture has never truly been a category of public action, constitutive of a political and national identity, unlike in France - except for the parenthesis of the Second World War, in a short-lived logic of "national spiritual defence" ("Geistige Landesverteidigung"; see f.e. Tanner 1992). This absence of cultural policy, which requires more study and data, might partly explain the irregular and relatively fractured character of Swiss research into the sociology of the arts and culture and, consequently, its proportionally weak development at an academic level. Nonetheless, teaching and research in sociology of the arts and culture do exist in this country, for example in Lausanne, Lucerne, St.Gallen and Zurich; however, they are not generally associated with chairs formally attached to this field. Even though the Swiss National Science Foundation (SNSF) has encouraged several investigations into this field since the 1990s, sociology of art does not correspond to a priority axis of research funding in Switzerland. Its position - more so, certainly, than that of sociology of culture therefore remains all the more fragile, since the logics of political-economic utility currently in force now translate, as far as the scientific realm is concerned, into new funding and career criteria, which discourage claims for specialisations deemed to be without direct professional profit nor immediate social outcome.

$6 \quad$ Numbers concerning the distribution of public subsidies began to be established as of the 1990s (Künzi 1994; Bourquin 1999; Tedeschi and Torche 2010).

7 Particularly since the year 2000, the last year where the OFS made a complete census of the population residing in Switzerland. It has been replaced ever since by annual surveys on a sampling of 200000 people from which tendencies are then extrapolated. 


\section{Analysing the arts from various viewpoints: the contributions to this special issue}

But let us now come to the texts gathered in the current issue and the arguments they advance. These contributions, as we will see, mobilise analytical tools which are likely to shed light on not only the vast and diversified world of the arts, but also other spheres of labour and employment. In this spirit, Pierre-Michel Menger establishes the exemplary character of the intermittent model which, in France, has inspired the employment/unemployment model negotiated and obtained by the consultants of wage portage companies. The author proposes an unprecedented comparison with this population who present a high level of qualifications in a niche market, which is also highly flexible. He questions the sustainability of such models, from the moment that they transfer the individual risk linked to these forms of employment onto the insurance system, in addition to being subject to strategic usage by employers in order to minimise their own costs. The author shows that all are not equal when it comes to the very entrepreneurial kind of management that is called for within this system: men over 50 are favoured the most, whereas women rarely find themselves in a situation where they can profit from a reduction in the number of their contracts, while still ensuring a comfortable level of income. This contribution falls into the larger current debate on the subject of "flexicurity", that is, a system capable of ensuring flexibility and security on the so-called "transitional" job markets (Gazier 2008), where the limits between employment and unemployment, salaried or freelance work, or even market and volunteer activity become blurred.

The article by Chloe Langeard tenders an analysis that is neither statistical nor socio-economical, but rather qualitative, of the modes of subjective appropriation of this public regulation system by intermittent entertainment workers (actors, technicians, etc) in France. She demonstrates how the precariousness linked to the discontinuity and uncertainty of contracts can be integrated as a positive identity resource; or conversely, how this can turn against entertainment workers. In the first case, a feeling of freedom, of putting the self into motion, of time freed up to create, opposes the idea of the imprisonment, stagnation and routine of continuous salaried work. In this respect, the author highlights the primordial role of a socialisation, which allows for the upholding of this intermittent status, which has become the primary factor for defining professionalism within an open labour market (where a diploma and a presence on stage are not sufficient to distinguish oneself from amateurs). Consequently, the inability to renew one's right to intermittent status because of a lack of redeemable hours acts as a disqualifier, since it signifies a judgment on quality. In this case, the positive value of this employment system can be completely reversed and criticised, because of the precariousness, exploitation and competition it generates. It can also lead to some forms of "loss of the self" (in a new round of opposition to values of authenticity and autonomy) and 
thus constitute a source of suffering. These results have been confirmed elsewhere (see Katz 2015), and they feed the questioning around the unequal means of facing uncertainty about one's employment, skills and assets within hyper-flexible markets (Castel 2009). Moreover, such uncertainties can pertain to the psychologising of disqualifications, which is actually created by this specific mode of work organisation (Linhart 2015).

Developing a case study about "ordinary musicians" in the French-speaking area of Switzerland, Marc Perrenoud and Pierre Bataille show that access to unemployment benefits plays an entirely incidental - not to mention exceptional - role in both their job retention rate and the definition of their professional status. Based on an innovative system of data collection (a respondent-driven sampling in eight waves), which they used given the absence of exploitable statistical data, the authors were able to determine the percentage of income stemming from musical activity, the origin of this income and therefore, the type of multi-activity they illustrate within the survey population. These results corroborate the existing scientific literature, which distinguishes the multiplication of activities within the artistic realm from that of its margins, or even outside it and threatening it (Menger 1997; Lahire 2006; Bureau et al. 2009). It is mostly the analysis of income composition which allows the authors to distinguish three ways of being a musician, unequally distributed from a social perspective. Although "craftsmen musicians" draw their income mainly from stage activities, they are also the least qualified, the most multi-active and the least affected by royalties. These royalties make up a large part of the income for "artist musicians", a minority group that is particularly subsidised, educated and masculine; whereas "teacher musicians" are more often in the later stages of their career. This study offers a good counterpoint to national and international surveys into the forms taken by multiplications of the self, induced by discontinuous shortor even very short-term employment.

Sarah Speck's contribution is located right in the heart of the issue surrounding the androcentric norms of artistic fields - which, in this regard, do not distinguish themselves from the so-called "conventional" labour markets, as in many other aspects (Maruani 2011). Through an interview-led approach, the author focuses on couples where the woman brings in the greater part of the income while the man pursues artistic or creative activities, thus analysing the ambivalent effects of the frittering of the "traditional" model in which the man provides for the needs of his family, within the particular context of the qualified urban middle classes guided by an ideal of equality. By taking an interest in the concrete distribution of income and household tasks, as well as the discourses held on the subject, the author sheds light on the potentials and arrangements, but also the lies and ambivalences of such a distribution. Indeed, she shows how these "artists", whose career and success is quite uncertain (they are painters, actors, musicians, or even makers of artistic signs), and whose activity is partly or entirely financed by their partner, manage to 
exempt themselves from some or even all of the household chores - all the while declaring that they personally take care of them. Via the mobilisation of the myth of the inspired artist - a typically masculine figure (Buscatto 2007; Krieger 2007; Ravet 2011) - we can see how the reaffirmation of an assignation to reproductive work operates in addition to a delegation of the productive work. Faced with this situation, the discourse of the female spouses is torn between the reaffirmation of progressive ideals and the renegotiation of a more traditional model (breadwinner, housewife) in order to escape this double sentence.

Isabelle Moroni - whose analysis contrasts the trajectories of a male and female artist - addresses the question of mobility, an essential factor for the structuration of artistic careers nowadays. The case of the Valais proves to be particularly interesting, since it shows how the demands of a now-globalised, so-called "contemporary" art scene impose themselves on cultural regions located on the periphery. On the basis of a qualitative approach centred on the analysis of emblematic individual cases, the author describes how this logic has spread via artist training systems in particular, without offering each individual the same opportunities, according to the "cosmopolitan" capital acquired and the aesthetic posture claimed. This case study offers a good example of the way in which mobility, alongside the prerequisite of international recognition (Quemin 2014; Glauser 2009; Bydler 2004), imposes a norm of flexibility and values of availability, adaptability and the constant redefinition of the self. This figure of the nomadic artist echoes a collective imagination according to which the classical norm of employment (permanent and within the same firm), associated with the disparaging figure of the civil servant, would no longer be topical (Caveng 2006). In order not to be endured, such geographical mobility apparently still needs to be linked with social resources, which are accessible differently according to one's social position and specific life course.

As for Pierre-Emmanuel Sorignet, he reveals to what extent cultural capital (cultural tastes, aesthetic competences, verbal ease, physical dispositions) turns out to be of primordial importance for one particular job market. Indeed, the field of contemporary dance functions on the basis of networks, which focus on elective affinities and diverse forms of social cooptation. Beyond the criteria of credentials and performance, the selection and election in the realms of art are founded on the personal qualities of individuals; in other words, social dispositions that are inherited or acquired during each person's trajectory. These inclinations can be contradictory and provoke productive or stigmatised discrepancies or, conversely, turn out to be congruent and obscure forms of social adjustments taken for granted. The author thus highlights the manner in which the elective mechanisms generally at work in the employment market - such as interpersonal or communication skills, a social acumen for playing the game, and providing the physical and moral representation expected within the occupied function - can materialise in the work relationship (Caveng 2006). Suffice it to say that the over-humanising of work (Linhart 2015), 
alongside a demand for the investment of one's own personal qualities, plays into the hands of social inequalities; in particular those of class and ethnicity, as is stressed by the author in a long-term ethnographic participatory approach with French dancers from working-class, and often immigrant, backgrounds.

Starting from the situation of writers, Carolin Amlinger endeavours to unpick the normative representations of "auctoritas" (the authority of the author), conceived as a process of construction, such as they are defended by German authors. These representations turn out to be diverse and reflect antagonisms between autonomous art and the capitalist market in the field of literature. Thanks to interviews conducted with twenty writers as well as ten experts of the literary field, the author analyses the forms of identity and the literary norms and practices which define four "types" of authors: the "establishment", whose affirmation of autonomy is directly dependent on a context and a position; the "bohemians", who have an idealised relationship with the mythical and anti-economist figure of the "artist" and live only partly off their art; the "bestsellers", who present themselves as liberated, not despite of but thanks to the market; and finally, the "word providers", writers who have an ambivalent professional existence, often working as ghostwriters. Through this approach, the author reformulates the framework developed by Nathalie Heinich (2000) in France, by linking these identity constructions to these authors' concrete conditions of existence. In doing so, she echoes other instances of French research into the literary field (Lahire 2006; Sapiro 2007), although this article's final contribution consists of an in-depth exploration of the contrasted refraction of the primacy of the market on literature and the figure of the author.

Like the text which introduces this volume, Denis Hänzi's contribution opens explicitly onto other sectors of activity and the work market in general. It concludes this series of articles and, in some ways, goes beyond the analysis proposed by a number of observers, especially French. Rather than seeing the artist as a model for understanding the future of the modern wage system, the author considers the dogma of creativity as a tyranny of "potentiality", at once general and clandestine; that is, a specific modality of perception which consists in detecting potential in individuals (or not). Although the "exemplary" model of the artist affirmed by some confirms the growing social importance of the relationship between art and capitalism, it mostly turns out to be an illusion. According to the author, this larger logic of potentiality is precisely the origin of the "forced marriage", diagnosed by some authors, between the exemplarity of the arts and the capitalist transformations that affect the market. Indeed, it structures sectors as varied as the theatre (a terrain he studies in more detail), banks, sport or the meat industry. The author picks up on this discourse of potentiality which, far from the myth of a creative imperative now omnipresent in the economy, actually fulfils an eminently conservative function, by reflecting the idea of innate possibilities which would not yet have had the 
opportunity to manifest themselves. ${ }^{8}$ Instead of leading to a desire to change the order of things, this would push towards self-limitation, resignation or acceptance of a professional and social status associated with an unsurpassable given. Labelled from then on as a "self-sufficiency algorithm", this "potentiality regime" (where artistic work is only one locus of actualisation) plays a problematic role, to say the least, in the regulation of the economic and social worlds.

What is the usefulness of the sociology of the arts and culture? To this slightly provocative question, one could reply - in light of the contributions gathered in the present volume - that by considering art as work (Becker 1982), it can be "used" to better understand a sector of activity which has undeniably been growing over the last decades. But it can also shed light on modalities of employment and work norms that obey a "new spirit of capitalism" (Sennett 2006). In the end, artists might only be exemplary because they have, for the most part, escaped the modern (sometimes described as "Fordist") model of employment linked to industrial capitalism, undermined nowadays by a financial capitalism which pushes norms to their paroxysm; norms which give top billing to values of autonomy, individual responsibility, creativity, innovation, or even potentiality. So these artists are not so much embodying the accomplished figure of the "inventive, mobile, hierarchychallenging, intrinsically motivated professional” (Menger 2002, 8-9), called for by the champions of this new social and economic order. Rather, they are testament to transformations happening elsewhere - and already mostly in action as far as they are concerned - such as the fragmentation of the wage system, the extreme individualisation of working relationships, the push towards an "entrepreneurial regime" (Borja and Sofio 2009) and, finally, the permanent risk, measure and evaluation of the self.

\section{References}

Abbing, Hans. 2006. Why Are Artists Poor? The Exceptional Economy of the Arts. Amsterdam: Amsterdam University Press.

Arendt, Hannah. 1959. The Human Condition. A Study of the Central Dilemmas Facing Modern Man. New York: Doubleday Anchor Days.

Becker, Howard S. 1982. Art Worlds. Berkeley: University of California Press.

Boltanski, Luc and Eve Chiapello. 1999. Le nouvel esprit du capitalisme. Paris: Gallimard.

Borja Simon and Séverine Sofio. 2009. Productions artistiques et logiques économiques: quand l'art entre en régime entrepreneurial. Regards sociologiques 37-38: 23-43.

Bourdieu, Pierre and Alain Darbel. 1966. L'amour de l'art. Les musées et leur public. Paris: Editions de Minuit.

8 The problematic of potentiality is not dissimilar to the recent critique of the notion of "talent" (Schotté 2012) and the more general debate on "the origin of inequalities in the arts" which led to an exchange of articles in France between Laurent Jeanpierre (2012) and Pierre-Michel Menger (2012). 
Bourquin, Jean-Christophe. 1999. Indicateurs des dépenses publiques pour la culture. Indices standardisés 1990-1996. Neuchâtel: Federal Statistical Office.

Bydler, Charlotte. 2004. The Global Artworld Inc. On the Globalization of Contemporary Art. Uppsala: Acta Universitatis Upsaliensis.

Bureau, Marie-Christine, Marc Perrenoud and Roberta Shapiro (eds.). 2009. L'artiste pluriel: démultiplier l'activité pour vivre de son art. Villeneuve d'Ascq: Presses Universitaires du Septentrion.

Buscatto, Marie. 2007. Femmes du jazz. Musicalités, féminités, marginalisations. Paris: CNRS Editions. Castel, Robert. 2009. La montée des incertitudes. Travail, protections, statut de l'individu. Paris: Seuil.

Caveng, Rémy. 2006. Quelques aspects du nouveau régime de subordination. Regards sociologiques 32: 5-21.

Danko, Dagmar. 2012. Kunstsoziologie. Bielefeld: Transcript Verlag.

Danko, Dagmar and Andrea Glauser (eds.). 2012. Soziologie der Künste. Themenheft der Sociologia Internationalis. Europäische Zeitschrift für Kulturforschung, Vol. 50, No. 1-2. Berlin: Duncker \& Humblot.

De Verdalle, Laure. 2006. Le théâtre en transition. De la RDA aux nouveaux Länder. Paris: Maison des sciences de l'homme.

Dubois, Vincent. 2013. La culture comme vocation. Paris: Raisons d'agir.

Ducret, André (ed.). 2011. A quoi servent les artistes? Zurich: Seismo.

Fabiani, Jean-Louis. 1986. Carrières improvisées: théories et pratiques de la musique de jazz en France. Pp 231-245 in Sociologie de l'art, edited by Raymonde Moulin. Paris: La Documentation française.

Gazier, Bernard. 2008. Flexicurité et marchés transitionnels du travail : esquisse d'une réflexion normative. Travail et Emploi 113: 117-128.

Glauser, Andrea. 2009. Verordnete Entgrenzung. Kulturpolitik, Artist-in-Residence-Programme und die Praxis der Kunst. Bielefeld: Transcript.

Grégoire, Mathieu. 2013. Les intermittents du spectacle. Enjeux d'un siècle de luttes. Paris: La Dispute.

Haak, Carroll. 2008. Wirtschaftliche und soziale Risiken auf den Arbeitsmärkten von Künstlern. Wiesbaden: Springer VS.

Hauser, Claude, Bruno Seger and Jakob Tanner (eds.). 2010. Entre culture et politique. Pro Helvetia de 1939 à 2009. Genève: Pro Helvetia/Editions Neue Zürcher Zeitung/Editions Slatkine.

Heinich, Nathalie. 2000. Etre écrivain. Création et identité. Paris: La Découverte.

Heinich, Nathalie. 2004 [2001]. La sociologie de l'art. Paris: La Découverte, coll. «Repères».

Jeanpierre, Laurent. 2012. De l'origine des inégalités dans les arts. Revue française de sociologie 53(1): 95-115.

Katz, Serge. 2015. Comédiens par intermittence. Le métier à l'épreuve de la disqualification professionnelle. Paris: Presses du Châtelet.

Klein, Gabriele and Bojana Kunst (eds.). 2012. On Labour. Special Issue Performance Research. A Journal of the Performing Arts, Vol. 17, Issue 6, London: Taylor \& Francis.

Kotte Andreas, Frank Gerber and Beate Schappach (eds.). 2012. Bühne \& Büro. Gegenwartstheater in der Schweiz. Zurich: Chronos.

Krieger, Verena. 2007. Was ist ein Künstler? Genie - Heilsbringer - Antikünstler. Eine Ideen- und Kunstgeschichte des Schöpferischen. Köln: Deubner.

Kuehni, Morgane. 2016. Les miettes du salariat. L'engagement au travail des sans-emplois. Travail, genre et sociétés 35(1) : 129-147.

Künzi, André. 1994. Dépenses publiques pour la culture et les loisirs. Dépenses de la Confédération, des cantons et des communes 1990. Bern: Federal Statistical Office.

Lahire, Bernard. 2006. La condition littéraire. La double vie des écrivains. Paris: La Découverte.

Linhart, Danièle. 2015. La comédie humaine du travail. De la déshumanisation taylorienne à la surhumanisation managériale. Toulouse: Editions Erès. 
Lorey, Isabell 2012. Die Regierung der Prekären. Wien: Turia + Kant.

Manske, Alexandra. 2015. Kapitalistische Geister in der Kultur- und Kreativwirtschaft. Kreative zwischen wirtschaftlichem Zwang und künstlerischem Drang. Bielefeld: Transcript Verlag.

Marchart, Oliver. 2013. Die Prekarisierungsgesellschaft. Prekäre Proteste. Politik und Ökonomie im Zeichen der Prekarisierung. Bielefeld: Transcript Verlag.

Maruani, Margaret. 2011. Travail et emploi des femmes. Paris: La Découverte, coll. «128».

Marx, Lisa. 2015. Exploring the configuration and strategies of interest groups in cultural policy making in Switzerland. Pp. 267-282 in Kunst und Öffentlichkeit, edited by Dagmar Danko, Olivier Moeschler and Florian Schumacher. Wiesbaden: Springer VS.

Menger, Pierre-Michel. 1991. Marché du travail artistique et socialisation du risque. Le cas des arts du spectacle. Revue française de sociologie 32(1) : 61-74.

Menger, Pierre-Michel. 1997. La profession de comédien. Formations, activités et carrières dans la démultiplication de soi. Paris: Ministère de la culture et de la communication.

Menger, Pierre-Michel. 2002. Portrait de l'artiste en travailleur. Métamorphoses du capitalisme, Paris: Seuil. Menger, Pierre-Michel. 2012. Réponse à Laurent Jeanpierre. Revue française de sociologie 53(1): 117-126.

Moeschler Olivier and Stéphanie Vanhooydonck. 2011. Les pratiques culturelles en Suisse. Analyse approfondie - enquête 2008. Neuchâtel: Federal Statistical Office.

Moeschler, Olivier. 2011. Le cinéma suisse. Une politique culturelle en action: l'Etat, les professionnels, les publics. Lausanne: Presses polytechniques et universitaires romandes.

Péquignot, Bruno. 2009. Sociologie des arts. Paris: Armand Colin.

Quemin, Alain. 2014. International Fame, Success and Consecration in the Visual Arts. A Sociological Perspective on Two Rankings of the Top 100 Artists in the World: The "Kunstkompass" and the "Capital Kunstmarkt Kompass". Pp. 345-364 in Kunst und Öffentlichkeit, edited by Dagmar Danko, Olivier Moeschler and Florian Schumacher. Wiesbaden: Springer VS.

Ravet Hyacinthe. 2011. Musiciennes. Enquête sur les femmes et la musique. Paris: Editions Autrement.

Ravet, Hyacinthe. 2015. Sociologie des arts. Paris: Armand Colin, coll. "Cursus».

Rolle Valérie and Olivier Moeschler. 2014. De l'école à la scène. Entrer dans le métier de comédien.ne. Lausanne: Antipodes.

Sapiro, Gisèle. 2007. «Je n’ai jamais appris à écrire». Les conditions de formation de la vocation d'écrivain. Actes de la recherche en sciences sociales 168(3): 12-33.

Schallberger Peter and Bettina Wyer 2010. Praxis der Aktivierung. Eine Untersuchung von Programmen zur vorübergehenden Beschäftigung. Konstanz: UVK.

Schotté, Manuel (2012). Le don, le génie, le talent. Critique de l'approche de Pierre-Michel Menger. Genèses. Sciences sociales et histoire 93: 144-164.

Sennett, Richard. 2006. The Culture of the New Capitalism. New Haven: Yale University Press.

Smudits, Alfred. 2013. Kunstsoziologie. Lehr- und Handbuch der Soziologie. München: Oldenbourg Verlag.

Steuerwald, Christian (ed.). 2016. Klassiker der Soziologie der Künste. Prominente und bedeutende Ansätze. Wiesbaden: Springer VS.

Tanner, Jakob. 1992. Zwischen «American Way of Life» und «Geistiger Landesverteidigung». Gesellschaftliche Widersprüche in der Schweiz der fünfziger Jahre. Unsere Kunstdenkmäler 43(3) : 351-363.

Tawfik, Amal. 2013. Culture et classes sociales: goûts musicaux, comportements culturels et distinction. Doctoral thesis, Sociology, University of Geneva, Switzerland.

Tedeschi, Umberto and Stéphanie Torche. 2010. Les dépenses publiques en faveur de la culture en Suisse, 1990-2007. Contributions de la Confédération, des cantons et des communes. Neuchâtel: Federal Statistical Office.

Walzer, Pierre-Olivier. 1988. A vot' bon ccur, m’sieu'dames: petit traité de mendicité culturelle. Genève: Editions Zoé. 


\section{Seismo}

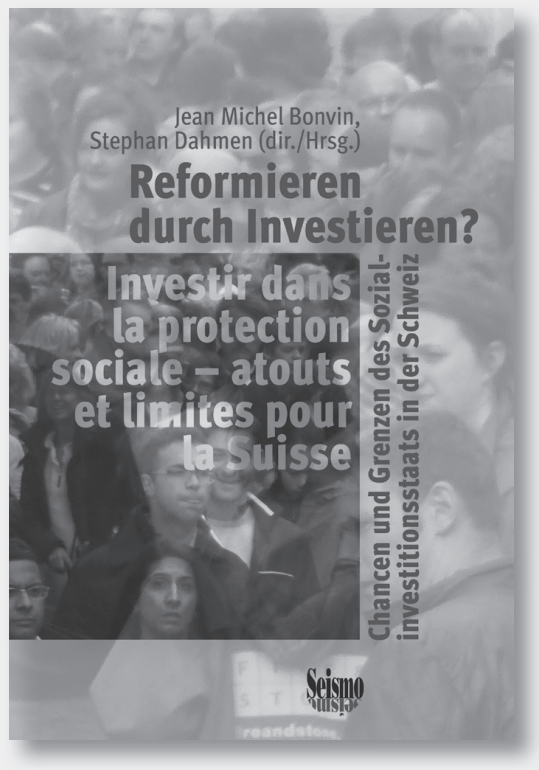

L'Etat d'investissement social se présente comme une stratégie de réforme de l'Etat social en vue de répondre aux nombreuses critiques auxquelles il est actuellement soumis. La conversion des États sociaux européens à l'investissement social vise ainsi à restaurer leur légitimité et à relever les défis démographiques et économiques posés aux États sociaux contemporains. Suivant les partisans de cette conception, la réorientation des dépenses sociales vers l'investissement dans la formation et le développement du capital humain notamment en facilitant l'accès à l'emploi, en accroissant les investissements dans les enfants et en privilégiant une nouvelle conception de la politique sociale comme facteur productif - permettra de réduire les inégalités sociales et de contribuer à la viabilité des États sociaux contemporains. Cet ouvrage examine la forme prise par l'investissement social en Suisse et les effets qui en résultent. II discute de manière analytique et critique les fondements idéologiques et les implications pratiques de la stratégie de l'investissement social.

Jean-Michel Bonvin est professeur ordinaire de sociologie et de socioéconomie à l'Université de Genève, Stephan Dahmen est chargé d'enseignement et doctorant à la Faculté des Sciences de l'éducation de l'Université de Bielefeld. www.seismoverlag.ch/info@seismoverlag.ch

www.editions-seismo.ch/info@editions-seismo.ch
Jean Michel Bonvin

Stephan Dahmen (dir./Hrsg.)

\section{Reformieren durch Investieren?}

\author{
Chancen und Grenzen des \\ Sozialinvestitionsstaats in \\ der Schweiz
}

\section{Investir dans la protection \\ sociale - atouts et limites pour}

\section{la Suisse}

Mit Beiträgen in deutscher und französischer Sprache. Avec des contributions en allemand et en français.

144 Seiten/pages, SFr. 28.-

Als Antwort auf den zunehmenden Druck, mit dem sich der Sozialstaat konfrontiert sieht, hat sich das Konzept sozialer Investitionen als Reformstrategie entwickelt. Der sozialinvestive Umbau europäischer Wohlfahrtsstaaten verspricht sowohl Antworten auf drängende Legitimationsfragen als auch auf gegenwärtige demografische und ökonomische Herausforderungen des Wohlfahrtstaates zu liefern. Die Neuausrichtung der Ausgaben des Sozialstaates auf Investitionen in Humankapital, etwa durch die Verbesserung des Zugangs zu Beschäftigung, den Ausbau der Investitionen in Kinder und eine konsequente Neubestimmung von Sozialpolitik als Produktivfaktor ermögliche es sowohl bestehende soziale Ungleichheiten zu reduzieren als auch die Nachhaltigkeit moderner Wohlfahrtstaaten zu gewährleisten. Welche Ausprägungen hat das Sozialinvestitionsparadigma in der Schweiz angenommen und welche Auswirkungen ergeben sich aus dem sozialinvestiven Umbau des Sozialstaates? Das Buch liefert eine kritische Analyse und diskutiert die ideologischen Grundlagen und praktischen Implikationen sozialer Investitionen.

Jean Michel Bonvin ist Professor an der Fachhochschule Westschweiz (éésp) Waadt und Lehrbeauftragter an der Universität Genf. Stephan Dahmen ist Lehrbeauftragter und Doktorand in Erziehungswissenschaften an der Universität Bielefeld. 